\title{
Scope Control Through Managing Changes in Construction Projects
}

\author{
Maja-Marija Nahod, M.Sc., M.Eng., Civ. Eng. \\ University of Zagreb, Faculty of Civil \\ Engineering \\ e-mail:majan@grad.hr,
}

DOI 10.5592/otmcj.2012.1.9 Research paper

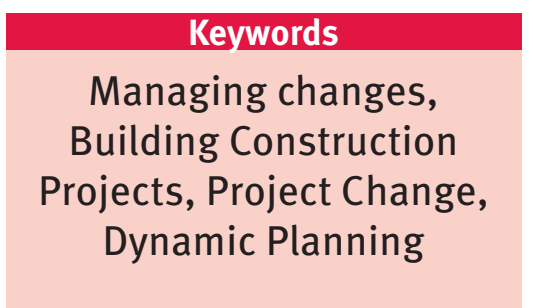

Projects need to be Performed and delivered under Certain ConSTRAINTS. Traditionally, these constraints are scope, time and cost. The Scope Control process influences the factors that lead to project scope changes and control the impact of those changes, which a key issue for project success. It ensures that all requested changes and recommended corrective actions are processed and that changes are reduced or eliminated if they result in negative impact on projects. The scope control is considered from the investor's point of view, as achieving the project goals is of primary importance for the investor. The theoretical basis for the research is Dynamic Planning and Control Methodology (“DPM"). Practical implications and adjustments are obtained, to result in an efficient system for managing changes throughout a project. Research was conducted through questionnaire and interviews. Findings include reasons for and consequences of changes from the point of view of various stakeholders in the project, as well as recommended procedures for objective and practical management of the changes. The study discusses the basic constraints: cost and time. Further research should focus on quantifying and determining the quality impact of changes and impact of the project manager's competencies on managing changes. The recommended procedures are applicable for any building construction project, but specific goals and constraints have to be incorporated into the calculation. Furthermore, a database of projects and changes could be created to facilitate preliminary assessments of the impact of changes on future projects.

\section{Introduction}

TResearchers have recognized the importance of scope management in construction projects as a key factor for project success. Scope management, which is directly connected with managing the changes required during the execution of projects, arises from the need for efficient and effective control over construction projects.

The existing research on scope and change management focuses on the identification of facts which influence 
the success of change processes, and studies best practice in the implementation of change management (Motawa et al. 2006). Examples of this type of research include: the concept of change management in a project (Construction Industry Institute (CII) 1994), best practice in effective change management (Cox et al. 1999), methods for reducing the total number of changes in construction projects (Stocks \& Singh 1999), best practice recommendations for effective change management (Construction Industry Research and Information Association (CIRIA) 2001) and advanced change management (Ibbs et al. 2001).

Scope management is responsible for the majority of project failures, which can be concluded from previous research. (see fig.1)
Scope management deals with the analysis and approval of changes in construction projects. One problem is the disparity between requested/potential changes in a project and changes which may be approved. Requests for changes in the later phases of a project must be rejected to a greater extent as they do not decrease quantitatively during the project life cycle, while the possibility of impact on the project decreases.

Hester and associates dealt with the evaluation of the effect of changes on certain elements of a project. They studied the influence of changes during construction on work productivity (Hester et al. 1991). Lee and associates developed models for the classification and quantification of losses in productivity resulting from changes in projects (Lee et al. 2004).

\begin{tabular}{|c|c|c|}
\hline & Critical factor & Reference \\
\hline 1 & $\begin{array}{l}\text { Change in initial project } \\
\text { expectations }\end{array}$ & $\begin{array}{l}\text { Balachandra and Friar (1997), Kumar et al. } \\
\text { (1996) }\end{array}$ \\
\hline 2 & $\begin{array}{l}\text { Change in overall project } \\
\text { importance to the organization }\end{array}$ & Kumar et al. (1996) \\
\hline 3 & $\begin{array}{l}\text { Change in need for the project (by } \\
\text { the organization) }\end{array}$ & $\begin{array}{l}\text { Balachandra and Friar (1997), Kumar et al. } \\
\text { (1996) }\end{array}$ \\
\hline 4 & Change in overall complexity & $\begin{array}{l}\text { Brockhoff (1994), Pate-Cornell and Dillon } \\
\text { (2001) }\end{array}$ \\
\hline 5 & $\begin{array}{l}\text { Change in overall time to } \\
\text { completion }\end{array}$ & $\begin{array}{l}\text { Balachandra and Friar (1997), Brockhoff (1994), } \\
\text { Pinto and Mantel (1990), Pohlman et al. (2003) }\end{array}$ \\
\hline 6 & Change in user needs & Balachandra and Friar (1997), Brockhoff (1994) \\
\hline 7 & $\begin{array}{l}\text { Change in overall project resources } \\
\text { (people, material, funds) }\end{array}$ & $\begin{array}{l}\text { Arkes and Hutzel (2000), Brockhoff (1994), } \\
\text { Pate-Cornell and Dillon (2001), Soman (2001) }\end{array}$ \\
\hline 8 & Change in technical difficulties & $\begin{array}{l}\text { Kumar et al. (1996), Pate-Cornell and Dillon } \\
\text { (2001), Pinto and Mantel (1990), Pohlman et } \\
\text { al. (2003) }\end{array}$ \\
\hline 9 & Change in funding source & Pate-Cornell et al. (1990) \\
\hline 10 & Change in regulatory problems & $\begin{array}{l}\text { Balachandra and Friar (1997), Kumar et al. } \\
\text { (1996), Pate-Cornell and Dillon (2001), Pinto } \\
\text { and Mantel (1990), Pohlman et al. (2003) }\end{array}$ \\
\hline 11 & $\begin{array}{l}\text { Internal politics (within the } \\
\text { organization) }\end{array}$ & $\begin{array}{l}\text { Allison and Zelikow (1999), Balachandra and } \\
\text { Friar (1997), Burgelman (1983), Miller and } \\
\text { Reuer (1996) }\end{array}$ \\
\hline 12 & $\begin{array}{l}\text { External politics to the } \\
\text { organization }\end{array}$ & $\begin{array}{l}\text { Allison and Zelikow (1999), Balachandra and } \\
\text { Friar (1997), Burgelman (1983) }\end{array}$ \\
\hline 13 & $\begin{array}{l}\text { Change in commitment by project } \\
\text { champion }\end{array}$ & $\begin{array}{l}\text { Balachandra and Friar (1997), Brockhoff (1994), } \\
\text { Gioia and Chittipeddi (1991), Pinto and Mantel } \\
\text { (1990), Pohlman et al. (2003) }\end{array}$ \\
\hline
\end{tabular}

Figure 1 Critical factors in project failure (D.M. Dilts, K.R. Pence, 2006.)
Scientists agree that the multiplicity and complexity of requests for changes in construction projects have a significant impact on the financial flows of a project. Average costs incurred as a consequence of requests for changes in construction projects amount to $5-10 \%$ of the total project budget (Cox et al. 1999). In order to reduce the effect of the negative consequences of changes in construction projects, it is necessary to find a more effective approach than that of statistical planning and controls (Lyneis \& Cooper 2001).

Many researchers propose the use of system dynamics in the planning of activities (Love et al. 2000); (Williams et al. 1995); (Rodrigues \& Bowers 1996) and finding the causes of additional work in construction projects (Love et al. 1999). In addition, system dynamics methodology can improve decision making at a strategic level.

Investors are the most significant stakeholders' group in considering project goals and the scope component. They have short-term and long-term interests during the whole project life cycle. (see fig. 2)

This is the main reason that it is the investor's point of view that is considered. Research to date has for the most part been based on change identification, best practice in change management during the project life cycle and evaluation of the effect of change on individual project characteristics.

Identification and recommendations are not sufficient for effective and specific change management. Actual tools for predicting the impact of potential changes and the coordination of changes throughout the entire project are essential. There is a lack of research on the interaction between various effects of change, which can increase the impact of individual influences by many times. 


\begin{tabular}{|c|c|c|c|c|c|c|c|}
\hline \multirow{3}{*}{ Stakeholder } & \multicolumn{7}{|c|}{ Project's goals } \\
\hline & \multicolumn{3}{|c|}{ Regarding to project lifecycle } & \multicolumn{4}{|c|}{ Regarding to benefits } \\
\hline & Disposable & Short-term & Long-term & Economic & Social & Political & Marketing \\
\hline Investor & 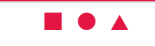 & $\square$ & $\square \bullet \Delta$ & $\square \bullet \Delta$ & $\square \bullet \Delta$ & $10 \Delta$ & $\square$ \\
\hline Contractor & $\boldsymbol{\square} \boldsymbol{\Delta}$ & $\boldsymbol{\square} \boldsymbol{\Delta}$ & 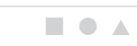 & $\square \bigcirc \Delta$ & $\square \bullet \Delta$ & $\mathbf{\Delta} \boldsymbol{\Delta}$ & - 1 \\
\hline Consultant & $\square \bullet$ & $\square$ & $\square \wedge$ & $\square$ & $\mathbf{0} \boldsymbol{\Delta}$ & $\boldsymbol{\Delta} \boldsymbol{\Delta}$ & $\square$ \\
\hline Financial institution & $\square \Delta$ & $\square \Delta$ & $\square$ & $\square$ & $\square \bullet \Delta$ & $\square$ & $\mathbf{0} \boldsymbol{\Delta}$ \\
\hline
\end{tabular}

Figure 2 Degree of interest of main construction project stakeholder in scope components

Legend:

\begin{tabular}{|c|c|c|c|c|c|}
\hline \multirow[b]{2}{*}{ Scope component } & \multicolumn{5}{|c|}{ Degree of interest } \\
\hline & $\begin{array}{c}\text { Extremely } \\
\text { high interest }\end{array}$ & $\begin{array}{c}\text { High } \\
\text { interest }\end{array}$ & $\begin{array}{l}\text { Medium } \\
\text { interest }\end{array}$ & $\begin{array}{c}\text { Weak } \\
\text { interest }\end{array}$ & $\begin{array}{l}\text { Without } \\
\text { interest }\end{array}$ \\
\hline Quality & $\mathbf{\square}$ & $\mathbf{\square}$ & $\mathbf{\square}$ & $\square$ & $\square$ \\
\hline Deadline & ○ & - & - & - & O \\
\hline Cost & $\Delta$ & $\Delta$ & $\Delta$ & $\Delta$ & $\Delta$ \\
\hline
\end{tabular}

The establishment of good bases for management prior to the project execution phase can contribute to better change management. It is therefore necessary during the planning phase to prescribe procedures for the verification of effects of change on the project plan. The proposed procedure will be described below.

With a systematic cycle from submission to the response to the request for change, the negative consequences of change can be significantly reduced.

\section{About the research}

research has been carried out on change management in Croatian construction practice, through questionnaires and interviews (Nahod 2010). A total of 24 questionnaires were processed, from key project stakeholders (8 construction project managers, 8 construction site managers and 8 investors). The questionnaires were distributed and completed in the presence of a researcher who provided clarification where needed. The questions were structured as open and closed. The respondents were first presented with open questions (30\%) and then closed questions (70\%).
The interview was used as a supplement to the questionnaire and obseropinion about experience and supplement the picture of the effects of change and change management systems in practice. Interviews were held with 18 key construction project stakeholders (6 project managers, 6 construction site managers and 6 investors in 6 large construction projects in the realization phase). The projects were selected in order to show current best practice in construction project management in Croatia. Observations revealed insufficient application of the world's proven procedures which are applied in Croatia only for the purpose of formally fulfilling contract obligations. The research results provided a basis for the systematization of changes in the realization phase of construction projects in Croatia. It also revealed the level of readiness for the implementation of change management procedures, which was taken into account in the drafting of procedures (Nahod 2010). The results of the research indicate that stakeholders in construction recognize the inevitability of change. It is not always possible to predict all the elements that effect construction projects, due to the level of complexity, the large number vation methods, in order to gain an of stakeholders and the influences of technology and organization. This creates the conditions for changes being required in projects. Change management is not systematically applied in Croatian construction projects. According to the research conducted, $80 \%$ of respondents are satisfied with the change management implemented in projects (which is worrying), although they recognize the negative consequences of changes in projects. Respondents consider that in $70 \%$ of cases of exceeding costs and deadlines in projects, the reason is changes that are approved without an objective assessment of the consequences in a project. The picture of change management in Croatia has provided a basis for measurement in which theory needs to be adapted to practice to obtain optimal results in the implementation of change management in construction projects (Nahod 2010).

\section{Systemizing changes in construction projects}

Systemizing changes could be performed by causes or consequences of the changes in projects. Research resulted in seven main causes of changes (see Table 1).

The main cause of construction changes are investor's requirements for higher standards in relation to those planned, to be realized in the execution phase of a construction project. All stakeholders are fully dedicated to a project and its details only in the execution phase, when they see 


\begin{tabular}{|c|l|c|c|}
\hline \multicolumn{1}{|c|}{ Cause of changes } & $\begin{array}{c}\% \text { of } \\
\text { changes }\end{array}$ & $\begin{array}{c}\text { Source of } \\
\text { change }\end{array}$ \\
\hline 1. & $\begin{array}{l}\text { Investor's change requests caused by additional } \\
\text { recognized needs for a project }\end{array}$ & $25 \%$ & $\begin{array}{c}\text { Project } \\
\text { stakeholders }\end{array}$ \\
\hline 2. & Partially incomplete project documentation & $21 \%$ & $\begin{array}{c}\text { Project } \\
\text { stakeholders }\end{array}$ \\
\hline 3. & $\begin{array}{l}\text { Change of technology caused by lack of availability of } \\
\text { designed technology in the market }\end{array}$ & $18 \%$ & $\begin{array}{c}\text { Project } \\
\text { conditions }\end{array}$ \\
\hline 4. & $\begin{array}{l}\text { Lack of concrete construction material in region caused } \\
\text { by high or low current demand }\end{array}$ & $12 \%$ & $\begin{array}{c}\text { Project } \\
\text { conditions }\end{array}$ \\
\hline 5. & Lack of financing for the timely completion of a project \\
\hline 6. & $\begin{array}{l}\text { Contractor's change requests for easier operations, } \\
\text { higher income, within the allowable limits for the project }\end{array}$ & $10,5 \%$ & $\begin{array}{c}\text { Project } \\
\text { constraints }\end{array}$ \\
\hline 7. & $\begin{array}{l}\text { Project documentation alignment with new regulations } \\
\text { adopted in the period between project design and } \\
\text { realization }\end{array}$ & $4 \%$ & $\begin{array}{c}\text { Project } \\
\text { stakeholders }\end{array}$ \\
\hline 8. & Other & $\begin{array}{l}\text { Project } \\
\text { conditions }\end{array}$ \\
\hline
\end{tabular}

of execution as a whole, an increase in expenditures and negatively effects on the quality of the works for the realization of the project. In practice this means temporary suspension of work on the project due to lack of funds to complete the project. Incomplete project documentation, according to research conducted, mainly results in changes in the engagement of resources and consequently invokes organizational changes in the phase of realization.

\section{Table1 Causes of changes}

alternatives to achieving the goals. Incomplete documentation is a cause of change due to poor or neglected coordination on the part of all of the project's stakeholders. Deadlines for partial designs are too ambitious, while synchronization of all parts of a project is replaced with a buffer to enable timely project deliverables. This buffer is usually used for making up for lost time, instead of for synchronization that is subsequently neglected. . So documentation is ultimately composed of unadjusted parts and does not form the logic of the whole project. Investors sometimes change their priorities or for other reasons redirect financing, so a project can end up being cancelled due to a lack of funds (see fig 3). analysis is not adequate, it can have a negative impact on the project.

In this research, the consequences of changes are divided into six groups:

- Change in the project scope, which manifests as additional work

- Indirect impact on other parts of the project

- Time extension

- Cost overruns

- Negative impact on the quality of performed works

- Change in the engagement of resources on the project

It is clear that investors' requirements impact additional works the most (in $83 \%$ of projects with scope changes). Undermining the harmony of the whole project is usually the result of

\section{Adjusted dynamic planning and control methodology in croatian construction management}

The main purpose of Dynamic Planning and Control Methodology (DPM), which was developed in the Intelligent Engineering Systems Laboratory (Pena-Mora and Li, 2002), is to give project dynamic mechanisms to web oriented planning tools and manage the changes afterwards.

DPM (Pena-Mora \& Li 2002) integrates existing tools in one comprehensive mechanism to ensure flexible utilization with regard to conditions variability and constraints for any specific project. The DPM framework consists of four layers: the strategic core, the tactical layer, the operational layer and the interface layer.

\begin{tabular}{|c|c|c|c|}
\hline Investor & Designer & Contractor & Project Manager \\
\hline $\begin{array}{l}\text { Designer are insufficiently } \\
\text { involved in the project and } \\
\text { don't elaborate it in detail } \\
\text { The market is chaotic and } \\
\text { incomprehensible } \\
\text { Contractors only care about } \\
\text { earnings and neglect the } \\
\text { quality }\end{array}$ & $\begin{array}{l}\text { Investor often changes inputs } \\
\text { for the project } \\
\text { The investor underestimates } \\
\text { the importance and the time } \\
\text { required for design } \\
\text { The contractor does not } \\
\text { examine the bidding } \\
\text { documents sufficiently }\end{array}$ & $\begin{array}{l}\text { Design documentation is } \\
\text { incomplete } \\
\text { The investor has a new ideas } \\
\text { during the realization phase }\end{array}$ & $\begin{array}{l}\text { Investor disclaims liability } \\
\text { because he is not in the } \\
\text { profession, but wants to } \\
\text { impact on project management }\end{array}$ \\
\hline
\end{tabular}

\section{Figure 3 Causes of changes by main stakeholders}

The analysis of the consequences of change on project realization must be performed quickly and effectively, and certainly before making a final decision on change approval. If this incomplete project documentation in some parts of the project (in $84 \%$ of projects with undermining harmony). Lack of financing to complete a project usually causes an increase in the time
Since each project is unique, the DPM requires the modelling of a change management system for each project and all influences relevant to the project. It is a demanding task of great 
complexity to be commonly applied in practice (Nahod, 2010). Therefore, some adjustments have to be carried out to make the DPM method more applicable in construction praxis.

The general idea was to divide the layers into two main parts: strategic management and operational management. (see fig 4). Changes must be managed on the basis of integrated information from both of these. Overlooking either one of these two parts of management will lead to ineffective change management which will reflect negatively on the success of the project.

Strategic management represents the management actions undertaken for the purpose of meeting the strategic objectives of the project, which require the harmonization of execution time, costs, resources and project objectives with the strategy of the system of which the project is a part (Lee et al. 2006; Nahod, Radujković, 2011)

For the successful implementation of strategic management, the set of activities and participants in the project are not considered separately but as continuous elements in interaction.

Operational management refers to management actions in respect of the time and costs of execution and includes steps to be taken to satisfy strategic management.

One of the biggest differences between strategic and operational approaches in project management is that operational project management does not include changing the project's objectives.

Strategic and operational management have advantages and drawbacks. The application of strategic management enables the project leader to make quality decisions within the overall set mode of execution and within the project constraints. However, strategic management is not able to quantify exhaustive and detailed impact on a project.

On the other hand, operational management can quantify detailed impact on a project, but has no scope for changing the objectives and global information (on available time, costs and resources). Taking appropriate decisions in operational management partially depends on the strategic level of management.

In order to effectively manage a project, synergy and simultaneous respect for strategic and operational approaches is necessary.

\section{The Strategic Core - Analytic Hierarchy Process (AHP)}

Strategic management is recognized as critical for project success. It provides guidelines for operational management and makes decisions in the initial project phases. In this way, operational decisions are adjusted to the long-term influences on the project execution. For the purposes of adapting the DPM to Croatian construction practice, a simulation of the strategic core is simplified and incorporates AHP. It determines the priority of project objectives and the influence of requested changes on the achievement of these objectives. A project's objectives need to be measurable, achievable and realistic. It is necessary to define 3-8 main
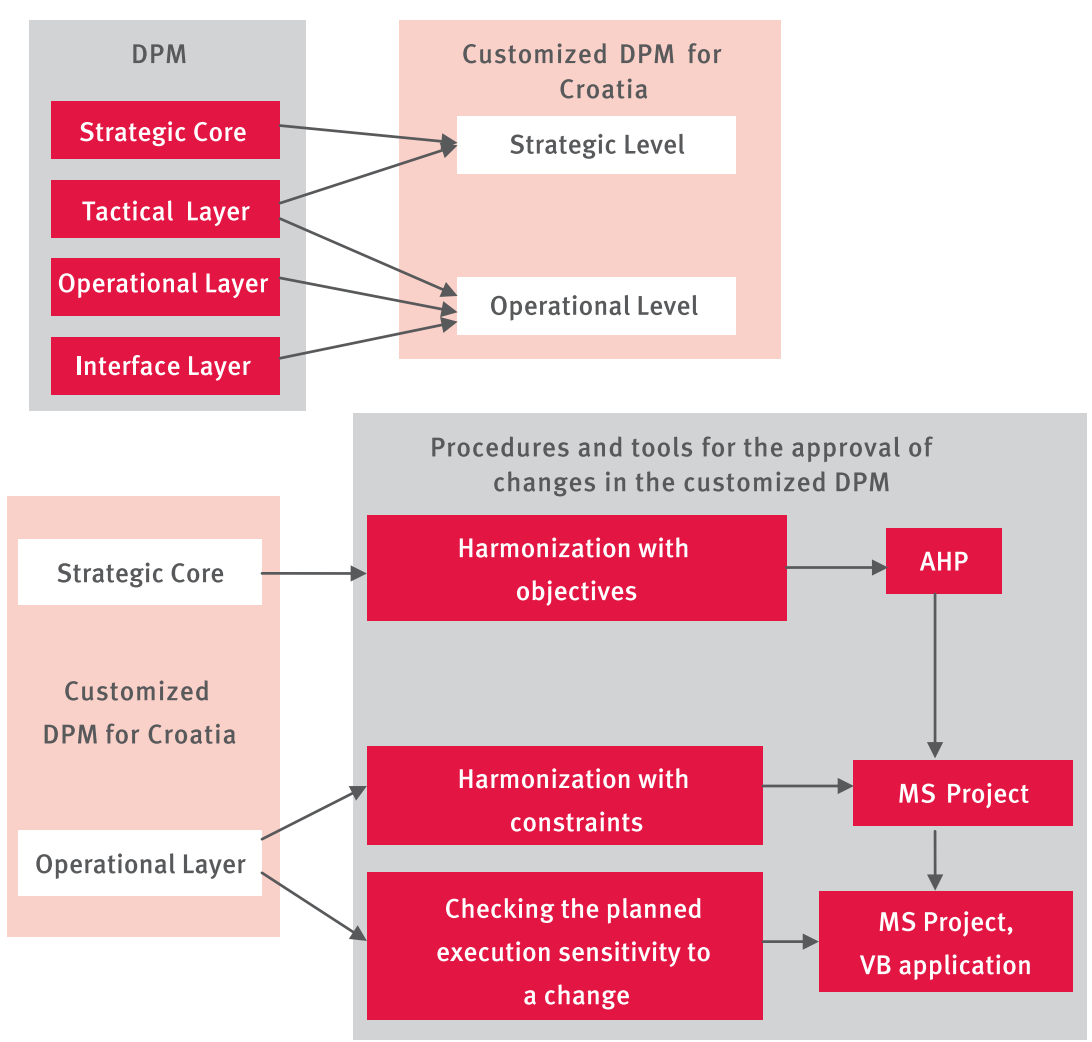

\section{Figure ${ }_{4}$ Customized DPM for Croatian Construction Practice}

Research has shown that Croatian construction practice has intensified change management principles and procedures during the last ten years, but still only in exceptional cases in large commercial systems and exclusively for the purpose of ensuring that planned project costs are not exceeded. project objectives, to determine their parameter of measurability during project execution and to determine their relative importance for the project. The project objectives have to be agreed with all relevant stakeholders, all the one-off, short-term and long-term objectives of the project. 
Is the change beneficial to the achievement of the project objectives or not? The strategic Core provides an answer to this question. The objectives should be clearly defined before project execution, otherwise it is impossible to implement this part of the procedure.

The approval or rejection of a change whose influence will be considered in the analysis shall represent alternatives to AHP. Software Expert Choice can be used for facilitation of the AHP process.

Comparison of objectives in pairs is performed for each level of the hierarchical objective structure to determine the weight of the importance of the objectives.

Testing change approval is performed for each specific objective, assessing the extent to which the change is in line with the specific objective. Then the local weight of the individual objective is calculated.

At the end of the AHP process the change is assigned a level of compliance with project objectives (expressed as a number between 0-1). The level of compliance is shown by the alternative "Approval of Change" so the local alignment is weighted with the weights of all nodes which belong, looking from the lowest level in the hierarchical model towards the highest level and then at the sum.

\section{The operational level of change management}

Operational management in the customized DPM covers the tactical, operational and interface layers of the DPM. Sine qua non is that the execution plan is approved and that it contains all necessary activities connected with adequate technological or organizational relationships.

The relationships between the activities are crucial for defining the dynam- ics and constraints. It is therefore very important for effective planning to have detailed modelling of all activity relationships, external and internal. External relationships refer to correlations between activities, while internal relationships refer to relationships within individual activities.

For DPM customization, network planning is relevant.

Critical Path Method (CPM) and Graphical Evaluation and Review Technique (GERT) have already been applied in construction.

The practical application of CPM is limited to cases where the construction is not subject to any significant limits of time or resources. In this context, an optimal plan is one that uses a hybrid approach and combines a few existing tools, taking from each its specific advantage in order to achieve maximum effectiveness of execution. The GERT method can actually manage feedback cycles in planning, but only for a static scope of work. Classic network-oriented tools are not effective in capturing cause-effect occurrence.

On the other hand, tools based on simulation have been created to reveal uncertainties in construction. The most commonly used are discrete simulations which focus on operational aspects of construction projects with the aid of stochastic process waiting time. Although simulation models prove useful at the operational level, they are only partially applicable for strategic management in construction. One possible reason for poor adjustment at the strategic level is a difficult process of development and natural focus on the operational level.

In determining the advantages and drawbacks of using certain planning tools, it is important to know which project characteristics are important for project management and to take into account the complexity and uncertainty at the strategic and operational level.

Construction can be defined as a process activity that is executed at variable locations with temporarily affiliated organizations and resources in an open environment. As a result, a high degree of unpredictability is constantly present.

It is obvious that existing tools may have difficulties with the understanding of dynamic characteristics in both strategic and operational management, due to the static approach of network-oriented tools and the operational approach of simulation-oriented tools.

Since changes are dynamic, good quality change management is only possible with the aid of tools that integrate a network-oriented simulation approach, DPM and include both strategic and operational aspects of project management.

The customized DPM incorporates all of the above and is applicable in Croatian construction practice.

\section{Change request analysis regarding to project constraints}

The main constraints are time and cost. The proposed methodology is recommended for application to all other specific project constraints as well.

It is necessary to define the threshold of reasonableness and the feasibility threshold for each constraint. The threshold of reasonability is marginally acceptable for the project ( $\left.o_{p o v}\right)$, and the feasibility threshold is the project constraint that must never be exceeded $\left(o_{\text {pov }}\right)$. 
For each constraint, $\mathrm{o}_{\mathrm{i}}(\mathrm{o}<\mathrm{i}<\mathrm{j})$ equals:

$$
f_{o i}=\left\{\begin{array}{cc}
1-\frac{o_{i, \text { real }}}{o_{i, i z v}}, & \text { if } 0<o_{i, \text { real }}<o_{i, p o v} \\
\left(1-\frac{o_{i, \text { real }}}{o_{i, \text { izv }}}\right) \cdot\left(1-\frac{o_{i, \text { real }}-o_{i, p o v}}{o_{i, i z v}-o_{i, p o v}}\right), & \text { if } o_{i, p o v}<o_{i, \text { real }}<o_{i, \text { izv }} \\
0, \text { if } o_{i, \text { real }}>o_{i, \text { izv }} \text { or } & 1, \text { if } o_{i, \text { real }} \leq 0
\end{array}\right\}
$$

where

$\mathrm{f}_{\mathrm{oi}}$ - The change approval factor for a specific constraint

$\mathrm{f}_{\mathrm{ki}}$ - The correction factor due to affordability constraints

$$
f_{k i}=\left(1-\frac{o_{i, \text { real }}-o_{i, p o v}}{o_{i, i z v}-o_{i, p o v}}\right),
$$

$o_{i, \text { real }}$ - The requested change effect value on the project dimension and unit of constraint measurement

$o_{i, i z v}-$ The feasibility threshold of constraint on the project

$o_{i, p o v}-$ The threshold of reasonability of constraint on the project

$o_{i, \text { real }} \leq 0$ if the change influences the planned constraint such that its effect is even more positive that the constraint is in the initial execution plan (i.e. for the given constraint, change is positive, e.g. when a change requires the replacement of one activity with another that has a more favourable constraint value than that of the original activity).

\section{Sensitivity of change to the Execution Plan}

Sensitivity of change to the execution plan is checked by testing the implementation of a change in the plan. As the project progresses, the degree of realization increases, but the possibility for influencing the project decreases. Research on changes in construction projects on the planned execution of four large construction projects in the City of Zagreb in the period from 2004 - 2009 led to the conclusion that for change management the crucial chain of activities is the longest chain of activ-
The application works as follows:

$\mathrm{n}_{1, \mathrm{t}}=1$,

(Initially for all non-summary activities) Let $t$ be the observed activity of the plan and $t 1$ is the activity preceding $t$. Then for each $\mathrm{t}_{1}(\mathrm{t})$ activity, calculate:

$$
n_{1, t}=\left(n_{1, t 1}+1\right) \text { if }\left\{\begin{array}{c}
n_{1, t 1} \geq n_{1, t} \\
s_{t 1}<s_{t}
\end{array}\right\}
$$

Where

resources and in all other aspects, which increases the level of diversity in a project. This cause often "warming up phases", the need for coordination and organizational obstacles. Some activities may then last for a shorter period, but the appearance of changes among them creates the potential risk of additional work and error.

In order to determine the sensitivity of a requested change in the execution plan, it is necessary to determine the activities in the execution plan that will be directly influenced by the change. If the change directly affects more than one activity, the average value of sensitivity is applicable. For the purpose of calculation, an application was developed in Visual Basic for MS Project which adds to each non-summary activity the value of its logical order in the network, on the basis of which it automatically calculates the sensitivity of the activity to a change.

The application adds three customized fields to each activity: $n_{1}, n_{2}$ and $\mathrm{n}_{3}$.

$n_{1, t}$ - a number which indicates the order of observed activity in the network plan, $\mathrm{n}_{1} \in \mathrm{N}$

$n_{2, t}$ - a number which indicates the sensitivity of the observed activity to a change, $n_{2} \in R, 0<n_{2}<1$

$n_{3, t}$ - a number which indicates the approval factor for the observed activity with respect to the sensitivity of the activity in the plan, $\mathrm{n}_{3} \in \mathrm{R}, \mathrm{o}<\mathrm{n}_{3}<1$ $n_{1, t 1}$ - The number which indicates the order of the preceding activity in the network plan, $n_{1} \in N$

$S_{t}$ - The date of commencement of observed activities in the plan $S_{t 1}$ - The date of commencement of the preceding activity in the plan

The procedure of increasing the value of $n_{1}$ is iteratively repeated until the system has completely stabilized (until $n_{1}$ is constant for each t activity). At this moment, balance has been achieved, which means that the $n_{1}$ variable contains the order of activities in the series of the network plan.

$\mathrm{n}_{1, \max }=\max _{\mathrm{i}=1}(\mathrm{n} 1, \mathrm{i})$,

where $\mathrm{n}$ is the number of activities in the plan

$\mathrm{n}_{2, \mathrm{t}}=\mathrm{n}_{1, \mathrm{t}} / \mathrm{n}_{1, \max }$,

$\mathrm{n}_{3, \mathrm{t}}=1-\mathrm{n}_{2, \mathrm{t}}=\mathrm{f}_{\text {pol,t }}$,

$f_{p o l, t}-$ The change approval factor with respect to the activity sensitivity to which the change relates directly

If $t_{i}(i=1, . . n)$ are all activities in the plan which are directly related to the observed change, then the following is valid:

$$
f_{p o l}=\frac{\sum_{i=1}^{n} f_{p o l, i}}{n}
$$


which means that the impact of the sensitivity of the activity to change is the mean value of sensitivity for all planned activities that are directly related to the change.

\section{Total impact of change on planned execution}

At the end, the approval impact of the change is integrated in respect of its compliance with the objective, the influence of all relevant constraints in the project on the potential approval of the change and the impact of sensitivity.

The final approval factor $f_{\text {odo }}$ is:

$f_{\text {odo }}=\frac{f_{\text {cilj }}+\sum_{i=0}^{j}\left[\left(f_{\text {oi }} \cdot f_{\text {ki }}\right)+f_{f}\right]+f_{\text {pol }}}{j+2}$

(9)

Where

$f_{\text {cilj }}$ - Approval change factor with respect to compliance with the project objectives

$f_{o i}$ - Approval change factor with respect to the impact of the change on constraint

$f_{k i}$ - Correction factor with respect to the reasonability of the constraint

$f_{f}$-Correction factor with respect to the flexibility of the constraints, $f_{f}$ $\leq 0.15$

$f_{\text {pol }}$-Approval change factor with respect to the sensitivity of the activity to change $j-$ Number of constraints in a project to be taken into account in the calculation

The value of the approval factor can be interpreted as follows:

$f_{\text {odo }}>0.5 \ldots$ the change is acceptable according to the customized DPM

$f_{\text {odo }} \leq 0.5 \ldots$ the change is not acceptable according to the customized DPM

The recommended procedures are derived from three main steps that check the impact of a requested change on project objectives, constraints and the timely execution of the plan (see fig 5). To begin with, it is crucial to have a real project plan on which further procedures depend. These procedures are the result of the integration of theoretical and practical aspects of managing changes in construction projects.

\section{Conclusions}

Scope management is one of the angles of the project management triangle, which means that together with time and cost it represents one of the most significant constraints and focuses on the project. There can be no project success without a systematically and professionally appointed system for managing the scope. Scope control is achieved through managing changes. The theoretical basis for the managing the changes is developed, but without adjustments to readiness of construction industry it can't have greater applications. The customized DPM method combines theory and practice into an effective tool for making decisions in respect of approving (or rejecting) requested changes. It enables quantification of the impact of a requested change on project objectives, constraints and compliance with the initial project execution plan. All parts of the procedures and their preconditions are determined. The proposed model provides an objective and comprehensive solution for scope management in construction projects. Further research should focus on the improvement of quality in the calculation of change impact as well as verification of the impact of a project manager's competencies on managing changes. A database of projects and changes could facilitate the preliminary assessments of the impact of changes in future projects. Finally, managing the changes and scope control contributes directly to the achieving project success. 


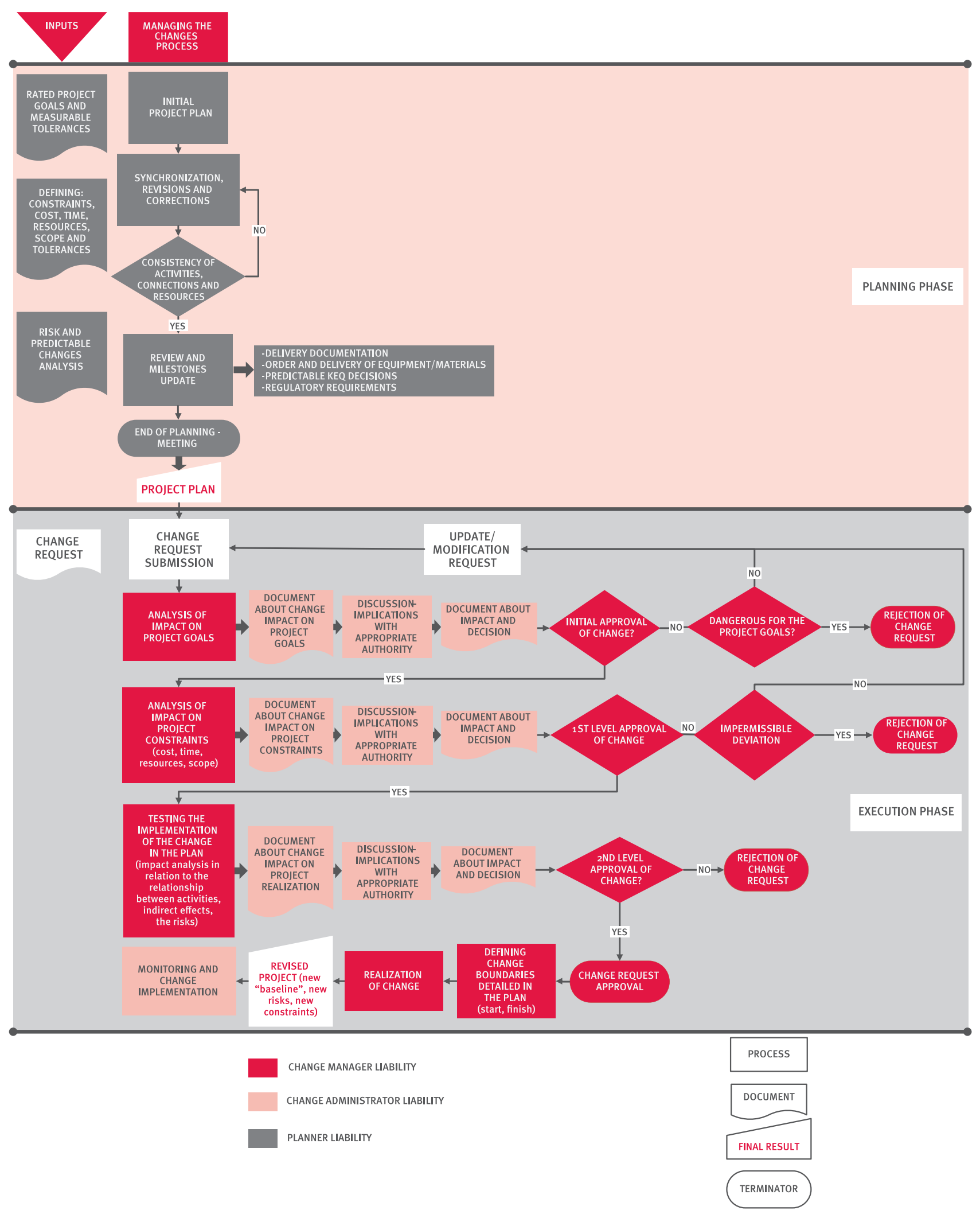

Figure 5 Procedures for managing changes 


\section{References}

Construction Industry Institute (CII) (1994), Project change management. Research Team, Special publication 431, Austin: The University of Texas, SAD Construction Industry Research and Information Association (CIRIA). (2001). Managing project change - a best practice guide

Cox, I., Morris, J., Rogerson, J., \& Jared, G. (1999), “A quantitative study of post contract award design changes in construction", Construction Management and Economics, 17/4 , 427-439

D.M. Dilts, K.R. Pence (2006), “Critical factors in Project Failure", Journal of Operations Management, 24 378-396 Hester, W., Kuprenas, J., \& Chang, T. (1991), "Construction changes and change orders: their magnitude and impact", Austin: Construction Industry Institute (CII)

Ibbs, C., Wong, C., \& Kwak, Y. (2001), "Project change management system", Journal of Management in Engineering ASCE, 17/3, 159-165

Lee, M., Hanna, A., \& Loh, W. (2004), "Decision tree approach to classify and quantify cumulative impact of change orders on productivity", Journal of Computing in Civil Engineering ASCE, $18 / 2,132-144$
Lee, S., Pena-Mora, F., \& Park, M. (2006), "Dynamic planning and control methodology for strategic and operational construction project management", Automation in construction, 15, 84-97

Love, P., Li, H., \& Mandal, P. (1999), "Rework: a symptom of a dysfunctional supply chain”, European Journal of Purchasing and Supply Management, 5/1, 1-11

Love, P., Mandal, P., Smith, J., \& Li, H. (2000), "Modelling the dynamics of design error induced rework in construction", Construction Management and Economics, 18/5, 575-586

Lyneis, J., \& Cooper, K. (2001), “Strategic Management of Complex Projects: A Case Study using System Dynamics", System Dynamics Review, System Dynamics Society, 237-260

Motawa, I., Anumba, C., \& El-Hamalawi, A. (2006), “A fuzzy system for evaluating the risk of change in construction projects", Advances in Engineering Software, 37, 583-591

Nahod M.M. (2010), “Upravljanje promjenama u fazi realizacije projekata visokogradnje" (Change Management in the Realization Phase of Construction Projects), Published MSc Thesis, Construction Management Department, Faculty of Civil Engineering, Croatia
Nahod M.M., Radujković, M. (2011), "Procedures for Change Management in the realization phase of Construction Projects", ARCOM (Association of Researchers in Construction Management), Annual conference / Charles Egbu, Eric Choen Weng Lou (ur.), Bristol: ARCOM, Association of Researchers in Construction Management

Pena-Mora, F., \& Li, M. (2002), “A Robust Planning and Control Methodology for Design-Build Fast-Track Civil Engineering and Architectural Projects", Journal of Construction Engineering and Management, ASCE, Reston, Virginia, 127/1, 1-17

Rodrigues, A., \& Bowers, J. (1996), "System dynamics in project management: a comparative analysis with traditional methods", System Dynamics Review 12/2, 121-139

Stocks, S., \& Singh, A. (1999), "Studies on the impact of functional analysis concept design on reduction in change orders", Journal of Construction Management and Economics 17, 251-267 Williams, T., Eden, C., Ackermann, F., \& Tait, A. (1995), "Vicious circles of parallelism”, International Journal of Project Management 13/3, 151-155 